\title{
SUBAXIAL CERVICAL FRACTURE: APPLICATION AND CORRELATION OF AO AND SLIC
}

\author{
FRATURA CERVICAL SUBAXIAL: APLICAÇÃO E CORRELAÇÃO DAS CLASSIFICAÇÕES AO E SLIC
}

\author{
FRACTURA SUBAXIAL CERVICAL: APLICACIÓN Y CORRELACIÓN DE \\ LAS CLASIFICACIONES AO Y SLIC
}

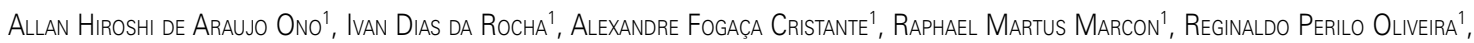
Tarcísio Eloy Pessoa Barros Filho ${ }^{1}$

\begin{abstract}
Objective: To evaluate the AO/Magerl classification and the SLIC (Subaxial Cervical Spine Injury Classification), used in the cervical spine fractures and assess whether they are correlated to the neurological severity of patients, the choice of approach to be used, de duration of surgery an between themselves. Method: Retrospective analysis of medical records and radiological image files of 77 patients surgically treated of subaxial cervical fracture or dislocation from August 2010 to September 2012. Results: The SLIC classification showed a strong correlation with neurological deficit and Pearson correlation value of -0.600 . The $\mathrm{AO}$ classification was not correlated with the Frankel scale and the value of Pearson was 0.06 with a statistical significance of $0.682(p<0.05)$, that is, unable to determine or suggest the severity of the deficit. When compared to each other the two classifications showed statistical correlation and the value of Pearson was 0.282 with a significance value of $0.022(p<0.05)$. Conclusion: Among the most used classifications, the SLIC has been able to statistically define the need for surgical treatment and the severity of the neurological status, but was unable to predict the approach or the time of the surgery; the classification $\mathrm{AO}$ failed to predict the severity of neurological injury, surgical time, and did not help to choose the approach, just being a morphological classification.
\end{abstract}

Keywords: Spinal fracture; Cervical vertebrae; Classification; Arthrodesis; Statistics, nonparametric.

\section{RESUMO}

Objetivo: Avaliar as classificações AO-Magerl e SLIC (Subaxial Cervical Spine Injury Classification) utilizadas em fraturas da coluna cervical e avaliar se elas apresentam correlações com a gravidade neurológica dos pacientes, com a escolha da via de acesso, a duração do ato cirúrgico e entre si mesmas. Métodos: Análise retrospectiva do prontuário e acervo de imagens radiológicas dos 77 pacientes submetidos à cirurgia de fratura e ou luxação da coluna cervical subaxial, no período de agosto de 2010 a setembro de 2012 . Resultados: A classificação SLIC apresentou forte correlação com déficit neurológico, com valor de correlação de Pearson de -0,600. Já a classificação AO não apresentou correlação com a escala de Frankel, e o valor de Pearson foi de 0,06 com significância estatística de 0,682 ( $p<0,05)$, ou seja, incapaz de determinar ou sugerir a gravidade do déficit. Quando comparadas entre si as duas classificações apresentaram correlação estatística e o valor de Pearson foi de 0,282 com valor de significância de 0,022 ( $p<0,05)$. Conclusão: Entre as classificações mais utilizadas, a classificação SLIC foi estatisticamente capaz de definir necessidade de tratamento cirúrgico e a gravidade do estado neurológico, porém foi incapaz de predizer a via de acesso ou o tempo de duração da cirurgia; a classificação AO falhou em predizer a gravidade da lesão neurológica, o tempo cirúrgico e em auxiliar a escolha da via de acesso, sendo apenas uma classificação morfológica.

Descritores: Fraturas da coluna vertebral; Vértebras cervicais; Classificação; Artrodese; Estatísticas não paramétricas.

\section{RESUMEN}

Objetivo: Evaluar las clasificaciones AO/Magerl y SLIC (Subaxial Cervical Spine Injury Classification) utilizadas en las fracturas de la columna cervical y evaluar si tienen correlación con la gravedad neurológica de los pacientes, la elección de la vía de acceso, la duración de la cirugía y si están correlacionados entre sí. Método: Análisis retrospectivo de registros médicos y colección de imágenes radiológicas de 77 pacientes tratados quirúrgicamente de fractura o dislocación de la columna cervical subaxial, desde agosto 2010 a septiembre 2012. Resultados: La clasificación SLIC mostró una fuerte correlación con déficit neurológico y el valor de correlación de Pearson de -0,600. La clasificación AO no se correlacionó con la escala de Frankel y el valor de Pearson fue 0,06, con una significación estadística de 0,682 ( $<<0,05)$, es decir, incapaz de determinar o sugerir la gravedad del déficit. Cuando se compararon entre sí, las dos clasificaciones mostraron correlación estadística y el valor de Pearson fue de 0,282, con valor de significación de 0,022 ( $p<0,05)$. Conclusión: Entre las clasificaciones más utilizadas, la calificación SLIC ha sido capaz de definir estadísticamente la necesidad de tratamiento quirúrgico y la gravedad del estado neurológico, pero fue incapaz de predecir la vía de acceso o la duración de la cirugía; la clasificación AO no logró predecir la gravedad de la lesión neurológica, el tiempo quirúrgico ni auxilió a elegir la vía de acceso, siendo sólo una clasificación morfológica.

Descriptores: Fracturas de la columna vertebral; Vértebras cervicales, Clasificación; Artrodesis; Estadísticas no paramétricas.

1. Universidade de São Paulo, School of Medicine, Hospital das Clínicas, Instituto de Ortopedia eTraumatologia, Spine Group, São Paulo, Brazil.

Study conducted at the Universidade de São Paulo, School of Medicine, Hospital das Clínicas, Instituto de Ortopedia eTraumatologia, Spine Group, São Paulo, Brazil. Correspondence: Rua Dr. Ovídio Pires de Campos, 333, Cerqueira Cesar, São Paulo, SP, Brazil. 05403-010. allanmed36@yahoo.com.br 


\section{INTRODUCTION}

Subaxial cervical fractures that occur between the third and seventh cervical vertebrae are major causes of morbidity in our society and the main causes of spinal injury, representing a high financial cost in both the health and social welfare sectors.

The estimated healthcare and social welfare costs for a 25-year-old patient with symptoms of traumatic tetraplegia and spinal cord injury between vertebrae C5 and C8 can be as high as 3 million dollars throughout the patient's life. In the United States 12,000 new cases of spinal cord injury occur every year, with $55.7 \%$ at cervical levels, and around $83 \%$ of patients that suffer this type of injury are young males. ${ }^{1,2}$

There is an ongoing debate regarding the pharmacological treatment of spinal trauma, as there is no consistent evidence relating to the use of neurostimulator or protective drugs. The use of methylprednisolone at high doses, previously advocated based on the NASCIS ${ }^{3}$ studies, has been abandoned by several institutions due to the lack of scientific evidence providing grounds for its use, and the high rate of complications resulting from the adverse effects of corticoids. Based on current evidence, this recommendation cannot, therefore, be made, ${ }^{4,5}$ and the orthopedic surgical or nonsurgical treatment of cervical fractures continues to be the central focus in these patients, while the decision regarding the type of treatment, and the method, is still discussed among professionals today.

Thus, countless classifications initially based on plain radiographs were proposed to facilitate communication, in an attempt to standardize treatment. The first publication related to this set subject is that of Böhler and Böhler, ${ }^{6}$ in 1929, who distinguish between fractures of the vertebral body and those of the neural arch.

The authors Whitley and Forsyth ${ }^{7}$ were the first to study the vectorial mechanisms of injuries, and to divide spine fractures into higher and lower cervical fractures, the mechanism of flexion, extension, compression, and combined fractures. In 1982, Allen et al. ${ }^{8}$ classified fractures into six groups each, and divided these into subgroups, covering almost all known fractures.

Dozens of other classifications that considered morphological and neurological aspects and vertebral stability were created and abandoned. ${ }^{9}$ None of these classification systems gained widespread acceptance due to their various limitations such as the retrospective reconstruction of the injury mechanism suggested by plain radiographs, making them subject to different interpretations for each observer. They also displayed a wide range of morphological subtypes, which made their use impracticable and difficult to reproduce. ${ }^{10}$

A classification for spinal fractures should be clinically relevant, i.e. usable as a prognostic tool, and should guide the treatment, help in the decision, and predict the possibility of complications. It should be reliable and reproducible, i.e. when repeated under similar conditions by different observers, or by the same observer, the results should be the same. The observer physician is the variable most susceptible to interpretation errors. It should also be accurate, i.e. the classification system represents, in reality, what it is intended to represent. ${ }^{11}$

The existence of several classifications for subaxial cervical fractures results in disagreement between the various institutions and between surgeons, and makes communication between medical specialists difficult, hampering scientific research, preventing the standardization of articles, and making the teaching of medical degree candidates even more of a challenge.

Today, among the many classifications, two that are used extensively and discussed by various authors are the classification of the AO Spine group, (Table 1) and that of the Spine Trauma Study Group. (Table 2)

The classification of the $\mathrm{AO}$ group (Arbeitsgemainchaft für Osteosynthesefragen) is based on the classification of thoracolumbar fractures of Magerl et al., ${ }^{12}$ published in 1994, and was adapted for cervical fractures from $\mathrm{C} 3$ to $\mathrm{C} 7$, using radiological findings and
Table 1. AO SPINE classification for lower cervical fractures (C3 - C7).

\begin{tabular}{c|c}
\hline \multicolumn{1}{c}{ Groups } \\
\hline \multirow{3}{*}{$\begin{array}{c}\text { Type A - } \\
\text { compression }\end{array}$} & A1 - Impaction \\
\cline { 2 - 2 } & A2- Split \\
\hline \multirow{3}{*}{$\begin{array}{c}\text { Type B - } \\
\text { distraction }\end{array}$} & A1- Burst \\
\cline { 2 - 2 } & B2- Posterior injury with intact vertebral body \\
\hline \multirow{3}{*}{$\begin{array}{c}\text { Type C - } \\
\text { rotation }\end{array}$} & B3- Anterior distraction - hyperextension \\
\cline { 2 - 2 } & C1- Unilateral facet fracture-dislocation A fracture \\
\cline { 2 - 2 } & C3- Separation fracture of articular mass + type A + type B \\
\hline
\end{tabular}

Table 2. SLIC Classification. ${ }^{10}$

\begin{tabular}{|c|c|c|}
\hline Morphology & $\begin{array}{l}\text { Ligamentous } \\
\text { complex }\end{array}$ & Neurological status \\
\hline No abnormality 0 pts & Intact 0 pts & Intact 0 pts \\
\hline $\begin{array}{l}\text { Compression } 1 \mathrm{pt} \\
\text { Burst }+1 \mathrm{pt}\end{array}$ & Undetermined $1 \mathrm{pt}$ & Root injury $1 \mathrm{pt}$ \\
\hline Distraction 3 pts & Torn 2 pts & $\begin{array}{l}\text { Complete spinal cord injury } \\
22 \mathrm{pts}\end{array}$ \\
\hline \multirow[t]{2}{*}{$\begin{array}{l}\text { Rotation or Translation } \\
\text { (facet dislocation) } 4 \text { pts }\end{array}$} & & $\begin{array}{l}\text { Incomplete spinal cord injury } \\
3 \text { pts }\end{array}$ \\
\hline & & Progression of deficit $1 \mathrm{pt}$ \\
\hline$\leq 3$ nonsurgical & $=4$ undetermined & $\geq 5$ surgical \\
\hline
\end{tabular}

pathomorphological characteristics of injuries in this segment. Three main mechanisms are considered: compression, called type A; flexion or distraction, type B and rotation, type C. Each type has three groups, with three subgroups, covering almost all of the fractures described in this region. ${ }^{5,12}$

In February 2015, the $\mathrm{AO}$ group published a new and more comprehensive classification for axial cervical fractures, which has not yet been translated into and validated for Portuguese, and is therefore not used in most education services in Brazil. ${ }^{13}$

In 2007, the Spine Trauma Study Group published a classification with the purpose of including a further two fundamental aspects in addition to radiographic morphological aspects: the integrity of the ligamentous complex and the presence of neurological deficit.

The three characteristics adopted as fundamental factors were: A) Morphological pattern of the injury, based on imaging tests and determined by the pattern of failure of the spines; ${ }^{14}$ B) Integrity of the ligamentous complex, represented by both structures and including posterior ligaments and anterior elements as well as the intervertebral disc; C) The patient's neurological status, including complete deficit, incomplete deficit and nerve root injuries. These three characteristics are widely recognized as predictors of prog- 
nosis, and directly influence the form of treatment. Each of these categories is divided into subgroups, identified and graded from the least to the most severe. At the end, the points are totaled and values of five or more are considered predictors of surgical treatment; values of three or less, of nonsurgical treatment; and values of four, an undetermined state, where the decision must be made at the surgeon's discretion, considering other aspects of the patient. ${ }^{10}$

This study therefore aims to correlate the two classifications in patients undergoing surgical treatment at the Instituto de Ortopedia e Traumatologia, evaluating the existence of equivalence between both, and whether these allow us to determine the severity and treatment approach.

\section{MATERIAL AND METHODS}

This is a transversal cohort study of quantitative nature. Study approved by the Institutional Review Board, IRB HCFMUSP opinion number 294.137.

Patients undergoing surgical treatment with a diagnosis of subaxial cervical fracture or subaxial cervical fracture-dislocation were selected from the database of Instituto de Ortopedia de Traumatologia do Hospital das Clínicas of the São Paulo School of Medicine between August 2010 and September 2012.

All the patients were required to have pre- and postoperative radiographs and preoperative CT scan available. The MRI exam was requested as mandatory in cases with partial neurological deficit and suspected lesion of the ligamentous complex.

Patients without suitable imaging tests in the electronic system, and those with tests carried out at other hospitals, incomplete radiological investigations, pathological fractures, and ankylosing spondylitis of the cervical spine, were excluded from the study, as the classifications used do not cover this type of fracture.

All the digital images stored in the server of Hospital das Clínicas were analyzed by a single observer, an experienced spinal surgeon, accustomed to daily use of the AO SPINE and SLIC classifications, with the aid of tools available in the Phillips iSite ${ }^{\circledR}$ software.

The cases were once again classified by the same surgeon using templates. Figure 1, published in the article by Marcon et al. ${ }^{5}$ was used for the AO classification, while the SLIC2 cell phone appli-

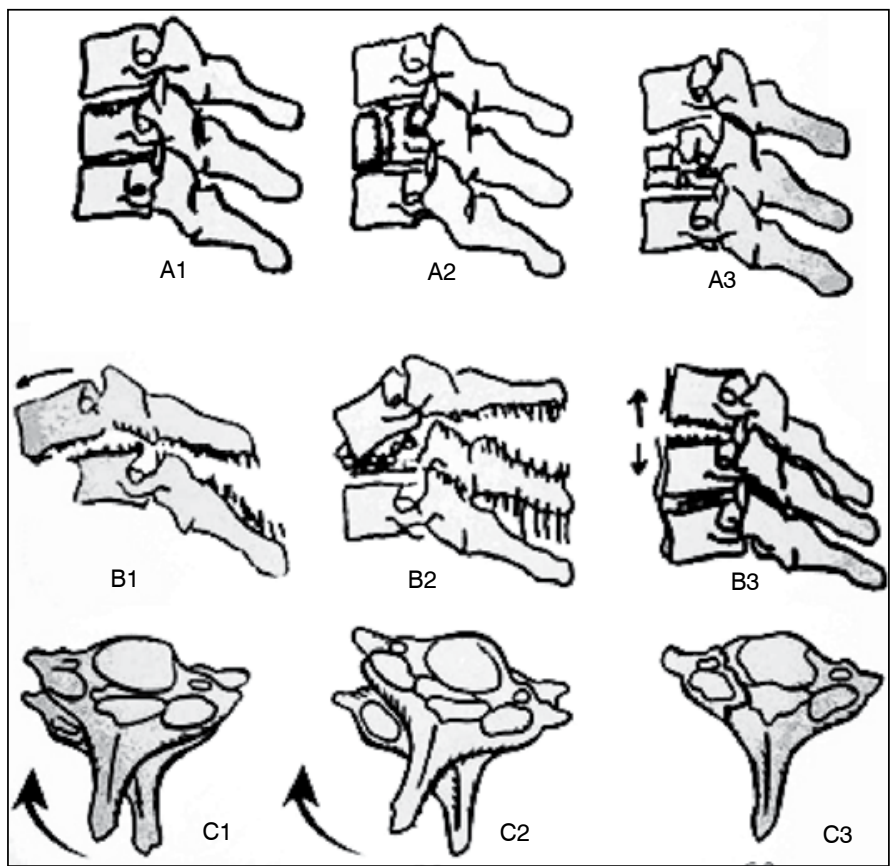

Figure 1. AO - Magerl 1994 classification for cervical fractures (Reproduced from Marcon et al. ${ }^{5}$ with the authors' permission) cation developed by Kubben ${ }^{15}$ and by the website digitalneurosurgeon.com with the collaboration of the authors of the Vaccaro et al. ${ }^{10,16}$ classification available on the Internet in the Android $^{\circledR}$ and Apple Store ${ }^{\circledR}$ platforms, was used for the SLIC classification.

In the case of the AO classification, the number five (5) was used to correspond to the axial skeleton, followed by the number one (1) corresponding to the cervical segment. The letter corresponds to the type, and the number after it corresponds to the group. The subgroups, which are represented by a "point" and number, were not considered, due to their low concordance. ${ }^{17}$

Severity criteria were also considered, such as: degree of neurological lesion on the Frankel scale, duration of surgical procedure, number of blood components transfused, levels of arthrodesis, approach, and previous use of a cranial halo for reduction.

\section{RESULTS}

Between August 2010 and September 2012, 77 patients underwent surgical treatment for cervical fracture in segments C3 to C7. The patients were aged between 15 and 82 years (averaging 36.5 years), the majority (88.3\%) males $(n=68)$. A total of 11 patients were excluded, seven due to lack of satisfactory radiological investigation, three presenting with fractures related to ankylosing spondylitis, and one with a pathological fracture.

Sixty-six patients remained within the inclusion criteria, 53\% $(n=35)$ without neurological deficit, classified as Frankel E, 33.3\% $(n=22)$ with complete deficit Frankel $A$, and $13.7 \%(n=9)$ with incomplete deficit Frankel D, C and B. Only three patients had associated spinal injury. Associated higher cervical fracture at $\mathrm{C} 1$ C2 was present in $7.6 \%(n=5)$.

The mean duration of the surgical procedure (from incision to dressing the wound) was 184 minutes, and only one patient required a blood component transfusion.

According to the $\mathrm{AO}$ classification, fractures classified as $51 \mathrm{~B} 1$ represented the majority $(25.8 \%)(n=17)$, followed by those of type 51B2 with $22.7 \%(n=15)$. (Figure 2$)$

When the SLIC classification was used, four patients (6\%) had scores of below four and were candidates for conservative treatment, while six patients (9\%) obtained scores of four, i.e., they were candidates for both types of treatment, with the decision being made at the surgeon's discretion.

Analyzing the surgical approach, $47 \%$ of the patients were operated by the posterior approach and $43.9 \%$ by the anterior approach, while $9.1 \%$ required a double approach.

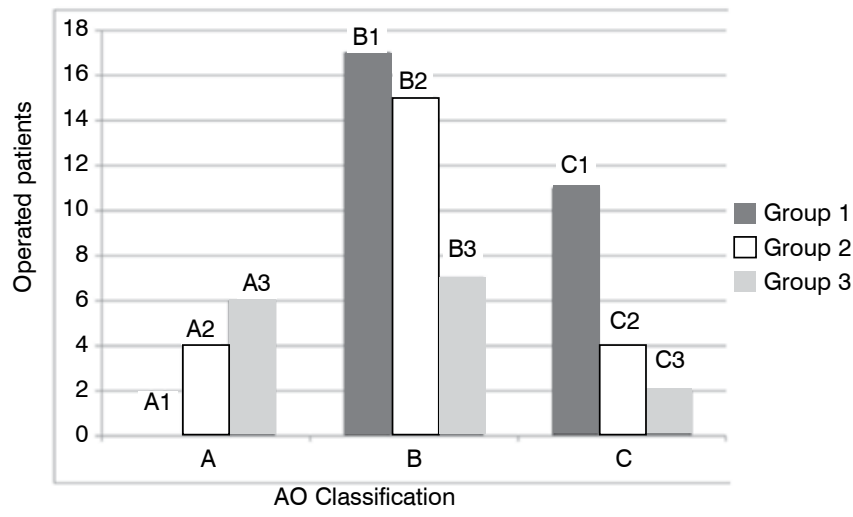

Figure 2. AO classification of the fractures in operated patients. 
To evaluate the classifications, we used Pearson's correlation test, considering statistically significant values below 0.05 . The classifications were initially tested in relation to the degree of neurological deficit using the Frankel scale.

When the SLIC classification was correlated with the neurological deficit scale, Pearson's correlation value was -0.600 , with statistical significance below 0.01. The AO classification did not present correlation with the Frankel scale, and the Pearson value was 0.06 with statistical significance of $0.682(p<0.05)$.

When we correlated the two classifications (SLIC and AO) (Figure 3), there was statistical significance. The Pearson value was 0.282 with a significance value of $0.022(p<0.05)$.

The test of correlation between the duration of surgery and the SLIC classification did not present significant results. (Pearson $=-0.200 p=0.117$ ) In relation to age, there was correlation with statistical significance (Pearson $=0.270$ with $p=0.028$ ).

\section{DISCUSSION}

The population made up of cervical fracture victims continues to consist predominantly men of productive age, with a proportion of $83 \%$, representing an extremely high socioeconomic cost.

Four of the operated patients had SLIC scores of below three, i.e., they were candidates for conservative treatment, according to the classification. Two of these patients required surgery due to association of higher cervical fracture with indication of fixation, and the other two presented symptoms of polytrauma requiring admission to the ICU, with indication of rapid removal of the neck brace in order to avoid pressure ulcers caused by the brace in contact with the patient's skin. Another six cases presented a score of four; according to the classification the treatment decision in these cases would need to be made by the surgeon. These cases were not analyzed separately.

No case with a score of less than three was operated on, demonstrating that the surgical indication of the team respects the patterns of instability of the SLIC classification, even without calculating the scores previously in all cases.

When the SLIC classification was compared to Frankel's neurological scale, there was a very strong correlation, as the former

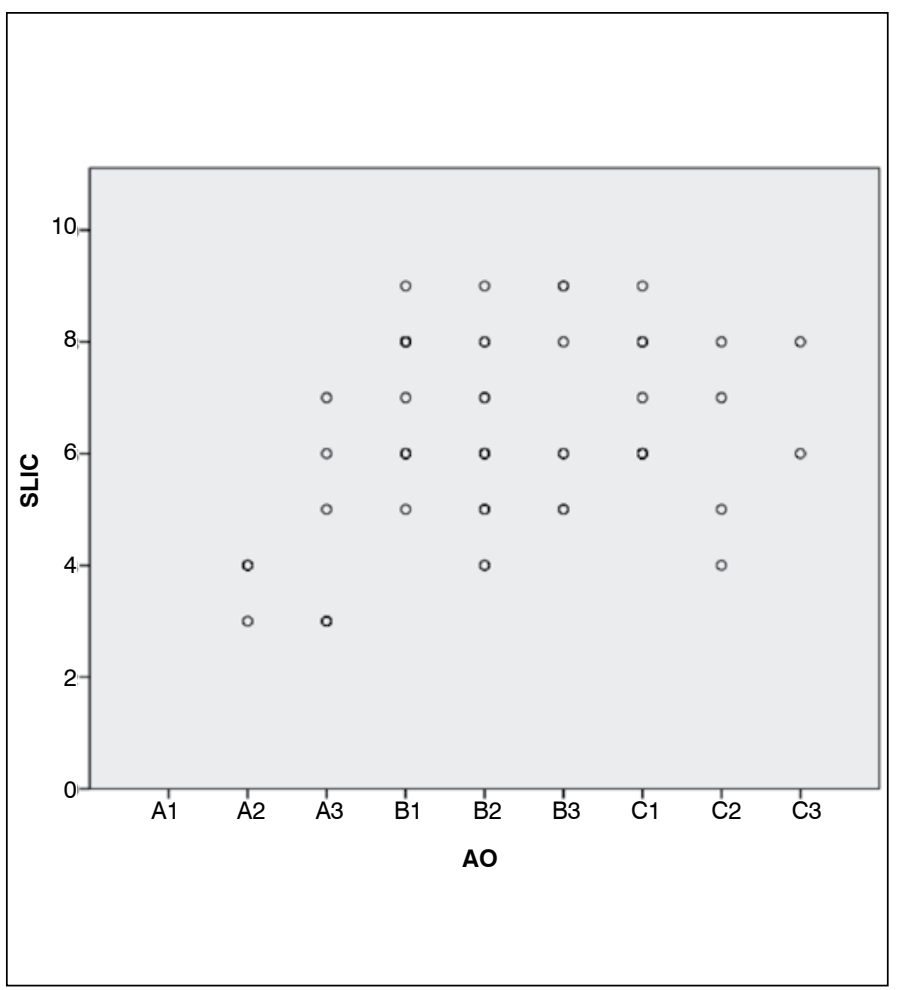

Figure 3. Correlation between the AO and SLIC classifications. uses neurological lesion as one of its criteria. Likewise, it was noted that the classification of the AO SPINE group does not have the same purpose, and that the progression from A1 to C3 did not accompany the neurological severity of the subject. Neither of the two classifications was correlated with surgery time. It is hypothesized that this may be related to other factors, such as the approach selected and the surgeon's experience.

The classifications presented a statistically significantly correlation with each another, due to the fact that the SLIC classification contains, in its morphological criteria, a scale similar to the classification of the $\mathrm{AO}$ group, if we consider only the segment and the type and group, and exclude the subtypes represented by "score" and number.

The SLIC classification proved to be a useful tool in the indication of surgical treatment, as $94 \%$ of the operated cases had a score of four or more, and cases with a score below four had surgical indication relative to associated higher cervical fracture, or contraindications for the use of immobilization. It also proved useful in determining neurological deficit, as the highest scores were associated with patients with partial or total neurological deficit, and it is useful for determining which cases should be prioritized.

The AO classification did not represent the severity of the cases, as it is a strictly morphological classification. Its gradation from A1 to C3 did not progress in keeping with the severity of the neurological deficit.

Both classifications presented here have been validated and have shown good intra- and interobserver evaluation results. ${ }^{17,18}$ The publication of a new AO classification in February 2015 takes into account other factors besides the morphological pattern of the fracture, which was also altered. In this current classification, any fractures with dislocation are classified as type $\mathrm{C}$, which are those in rotation, flexion or distraction. The neurological status and condition of the discs, ligaments and facets were also considered modifiers, and were included in this new classification. ${ }^{13}$

Independent data on inter- and intraobserver concordance were not published. To reduce interobserver concordance bias, we used a single observer, who analyzed the same images twice. The intraobserver concordance rate was not calculated, as this was not the objective of this study.

The classifications in our department are used routinely as a means of communication, but are not used prospectively. Surgical decisions are made based on the surgeons' experience during the daily visits. We believe that a prospective analysis of the classifications, and of the algorithms proposed by them, would make a considerable contribution. Yet even retrospectively, as demonstrated in this study, we noted that $94 \%$ of the operated patients had a score greater than or equal to four in the SLIC classification.

Chabbra et al. ${ }^{19}$ consulted several surgeons involved in academic hospitals about their perspectives and the existing classifications for subaxial cervical fractures. The results obtained show that the majority of departments (37.5\%) still use the Allen Ferguson classification, followed by the classification SLIC (35\%). The advantages discovered by these surgeons in relation to the SLIC classification, as compared to other classifications, were the fact that the SLIC takes into account the neurological deficit and its severity; it offers guidelines for the choice of treatment; and it promotes information about the severity of bone and ligament injuries, besides being a tool for future studies.

\section{CONCLUSION}

Both classifications should be taught and practiced in daily use by traumatologists, spine surgeons and neurosurgeons. They are easy to memorize, with satisfactory rates of inter- and intraobserver concordance, besides being important tools for facilitating communication and standardization of data for scientific studies.

Even though they are widely disseminated, the classifications shown in the study do not yet satisfactorily meet all the criteria of reliability and reproducibility, and are not being adopted by most surgeons. 
This is the first study comparing the two main classifications. Further studies are necessary to determine whether these classifications are correlated with the clinical outcomes of patients.

The adoption of new classifications for subaxial cervical fractures, such as the AO SPINE classification published in February 2015, as well as others that have emerged, should be studied at length before being used prospectively.
The surgeon's experience, as well as the patient's clinical and psychological aspects, should be taken into account when making the decision about the type of treatment, choice of approach, and method to be used.

All authors declare no potential conflict of interest concerning this article.

\section{REFERENCES}

1. Spinal Cord Injury Facts and Figures at a Glance. J Spinal Cord Med. 2014 Feb 21:37(3):355-6.

2. Letaif OB, Damasceno ML, Cristante AF, Marcon RM, lutaka AS, Oliveira RP, et al. The choice of surgical approach for treatment of cervical fractures. Coluna/Columna. 2010 Dec;9(4):358-62.

3. Nesathurai S. Steroids and spinal cord injury: revisiting the NASCIS 2 and NASCIS 3 trials. J Trauma. 1998 Dec;45(6):1088-93.

4. Botelho RV, Daniel JW, Boulosa JLR, Colli BO, Farias R de L, Moraes OJS, et al. Efetividade da metilprednisolona na fase aguda do trauma raquimedular: revisao sistemática dos ensaios clinicos randomizados [Effectiveness of methylprednisolone in the acute phase of spinal cord injuries: a systematic review of randomized controlled trials]. Rev Assoc Med Bras. 2009;55(6):729-37.

5. Marcon RM, Cristante AF, Teixeira WJ, Narasaki DK, Oliveira RP, de Barros Filho TEP. Fractures of the cervical spine. Clin São Paulo Braz. 2013 Nov;68(11):1455-61.

6. Böhler L, Böhler J. The treatment of fractures. Ed 5. New York. Grune \& Stratton, Incorporated; 1956

7. Whitley JE, Forsyth HF. The classification of cervical spine injuries. Am J Roentgenol Radium Ther Nucl Med. 1960;83:633-44.

8. Allen $B L$, Ferguson RL, Lehmann TR, O'Brien RP. A mechanistic classification of closed, indirect fractures and dislocations of the lower cervical spine. Spine. 1982 Feb; $7(1): 1-27$.

9. Defino H. Classificação das fraturas da coluna cervical baixa (C3-C7). Rev Coluna. 2003:2(1)

10. Vaccaro AR, Hulbert RJ, Patel AA, Fisher C, Dvorak M, Lehman Jr RA, et al. The subaxial cervical spine injury classification system: a novel approach to recognize the importance of morphology, neurology, and integrity of the disco-ligamentous complex. Spine. 2007:32(21):2365-74

11. Van Middendorp JJ, Audigé L, Hanson B, Chapman JR, Hosman AJ. What should an ideal spinal injury classification system consist of? A methodological review and conceptual proposal for future classifications. Eur Spine J. 2010;19(8):1238-49.

12. Magerl F, Aebi M, Gertzbein SD, Harms J, Nazarian S. A comprehensive classification of thoracic and lumbar injuries. Eur Spine J. 1994 Aug 1;3(4):184-201.

13. Vaccaro AR, Koerner JD, Radcliff KE, Oner FC, Reinhold M, Schnake KJ, et al. AOSpine subaxial cervical spine injury classification system. Eur Spine J Off Publ Eur Spine Soc Eur Spinal Deform Soc Eur Sect Cerv Spine Res Soc. 2015 Feb 26.

14. Holdsworth F. Review Article Fractures, Dislocations, and Fracture-Dislocations of the Spine. J Bone Jt Surg. 1970 Dec 1;52(8):1534-51.

15. Kubben PL. SLIC 2: Improved decision support for subaxial cervical spine injury. Surg Neurol Int [Internet]. 2012 Mar 14 [cited 2015 May 1];3. Available from: http://www.ncbi. nlm.nih.gov/pmc/articles/PMC3326985/

16. Spine Trauma Study Group Vaccaro A Hulbert R, Fisher C. Dvorak M, Patel A et al. The Sub-axial Cervical Spine Injury Classification System (SLIC): A Novel Approach to Recognize The Importance of Morphology, Neurology and Integrity of the Disco-ligamentous complex. Dep Orthop Surg Fac Pap [Internet]. 2006 Nov 8; Available from: http://jdc. jefferson.edu/orthofp/14

17. Wood KB, Khanna G, Vaccaro AR, Arnold PM, Harris MB, Mehbod AA. Assessment of two thoracolumbar fracture classification systems as used by multiple surgeons. J Bone Jt Surg. 2005;87(7):1423-9.

18. Alpesh A. Patel, Andrew Dailey, Darrel S. Brodke, Michael Daubs, Paul A. Anderson, R. John Hurlbert, et al. Subaxial cervical spine trauma classification: the Subaxial Injury Classification system and case examples [Internet]. http://dx.doi.org/10.3171/ FOC.2008.25.11.E8. 2008 [cited 2014 Feb 6]. Available from: http://thejns.org/doi/ abs/10.3171/FOC.2008.25.11.E8?url_ver=Z39.88-2003\&rfr_id=ori:rid:crossref.org\&rfr_ dat $=$ cr_pub\%3dpubmed

19. Chhabra HS, Kaul R, Kanagaraju V. Do we have an ideal classification system for thoracolumbar and subaxial cervical spine injuries: what is the expert's perspective? Spinal Cord. 2015 Jan;53(1):42-8 